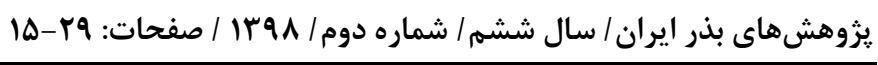

مقاله يثوهشى

اثر تيمارهاى شكست خواب بر جوانهزنى و فعاليت آنزيم آلفا آميلاز بذر سه اكوتيب كون

مر تعى (Astragalus cyclophyllus)

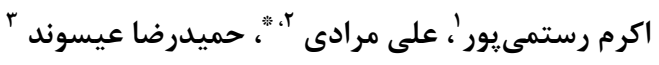

جكيده مبسوط

مقدمه: حالت خواب بهعنوان يك شيوه اجتناب از تنشهاى اقليمى اهميت زيادى در حفظ كونههاى كياهى دارد كه شامل خواب

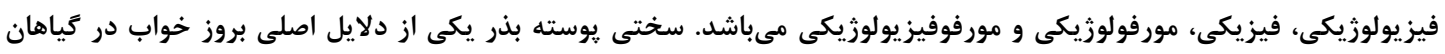

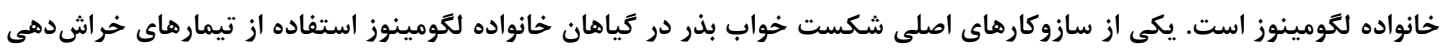

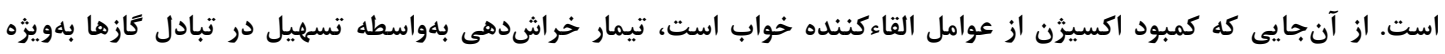

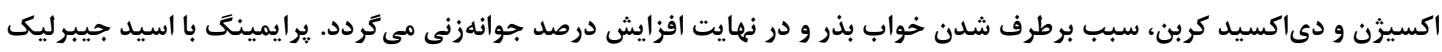

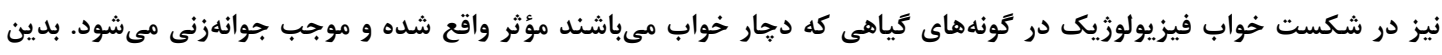

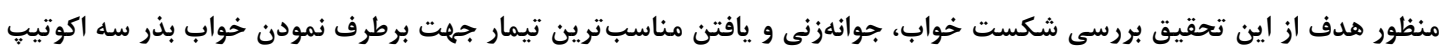
كون مر تعى ميىباشد.

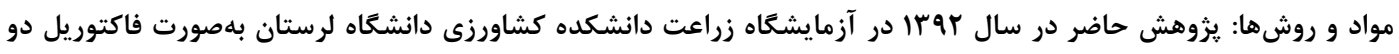

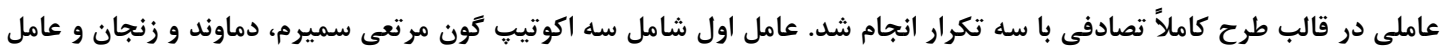

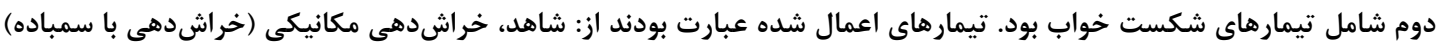

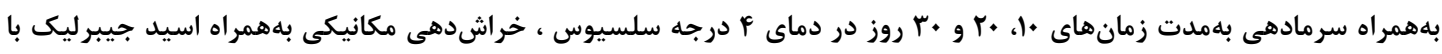

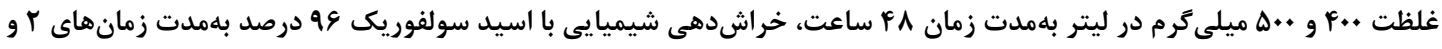

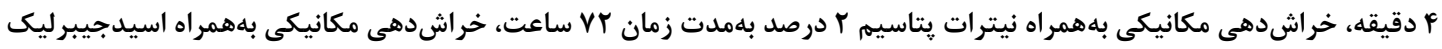

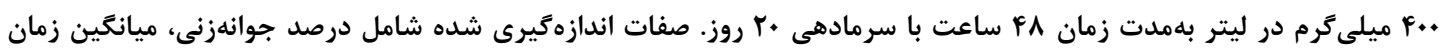

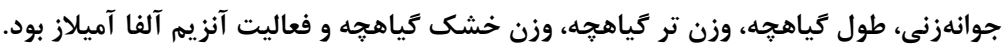

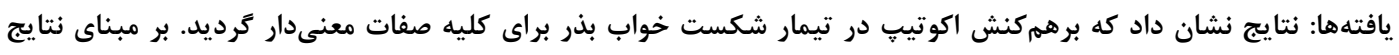

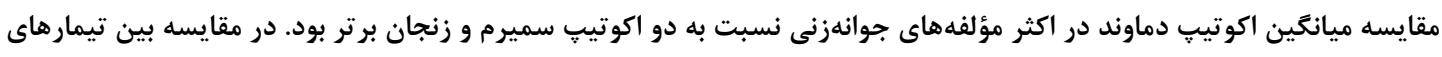

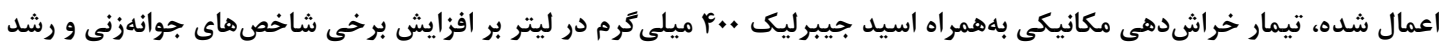

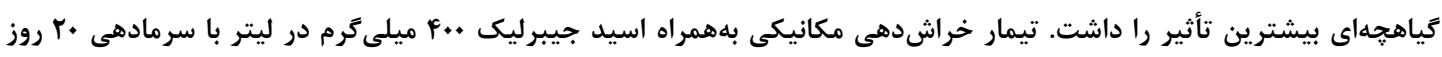

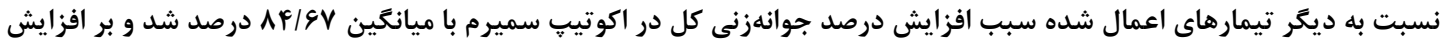

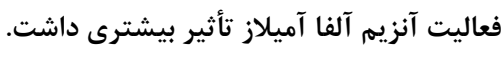

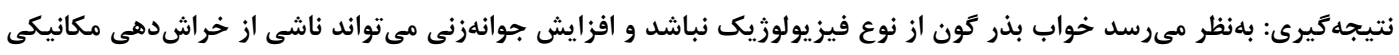

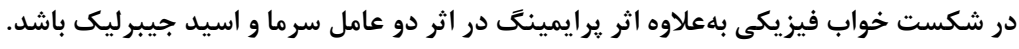

http://dorl.net/dor/20.1001.1.23831251.1398.6.2.7.9 http://dx.doi.org/10.29252/yujs.6.2.15

CrossMark

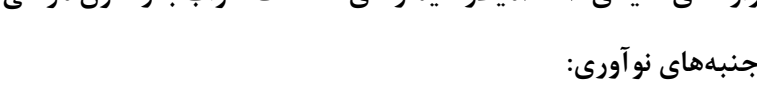

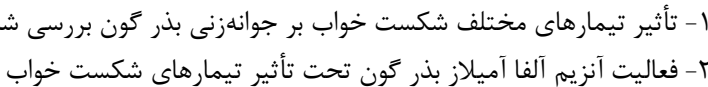


و زمان برداشت بستگى زيادى دارد. نتايج نشان مىدهد تنوع بالا در طول سالها در خواب فيزيكى كونهها

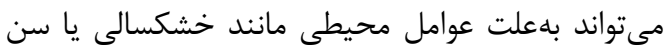

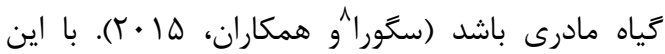
وجود، گاه خواب بذر بهصورت ويزگى نامطلوبى بهنظر

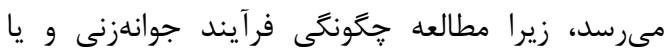

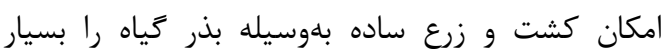

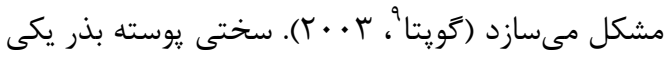

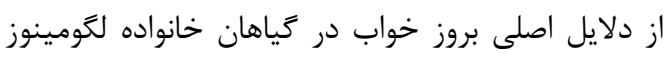

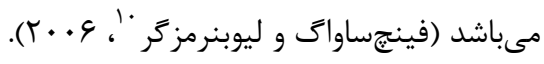

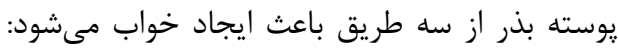

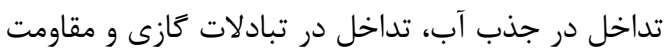

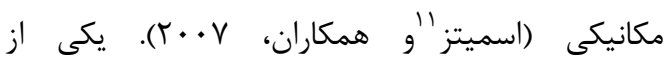
سازوكارهاى اصلى شكست خواب بذر در كياهان خانواده

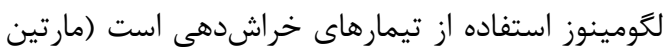

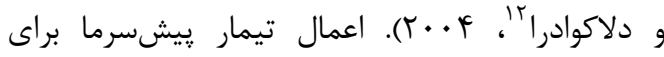

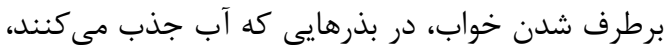

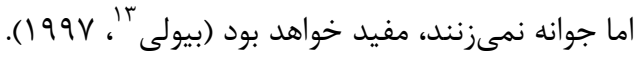

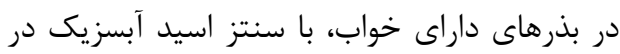
جنين فعاليت آلفا آميلاز از طريق كاهش ميزان بان اسيد

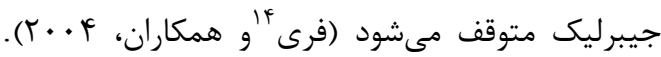

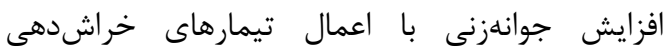
مكانيكى (كاغذ سمباده) و شيميايى (اسيد سولفوريك)، سرمادهى و اسيد جيبرليك در بذرهاى سه نوع كَّن و

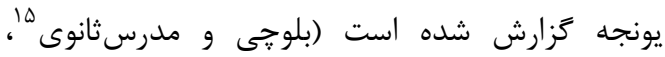

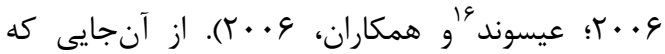
كمبود اكسيرن از عوامل القاء كننده خواب است، شايد

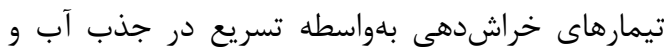

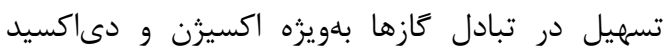
كربن و تيمار سرمادهى بهواسطه اثرى كه در برطرف

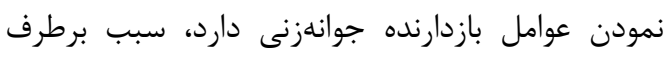

\footnotetext{
${ }^{8}$ Segura

${ }^{9}$ Gupta

${ }^{10}$ Finch-Savage and Leubner-Metzger

${ }^{11}$ Schmitz

${ }^{12}$ Martin and De la Cuadra

${ }^{13}$ Bewley

${ }^{14}$ Frey

${ }^{15}$ Balouchi and ModarresSanavy

${ }^{16}$ Eisvand
}

مقدمه

Fstragalus ) (

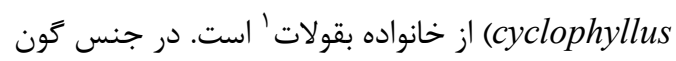
تركيباتى نظير : يلىساكاريدها، ويلىفنلها، سايونينها و

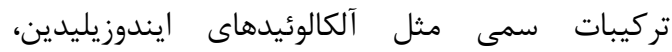
كاستانوسيرمين، آستراكالوزوئيد، تركيبات نيتروآليفاتيكى

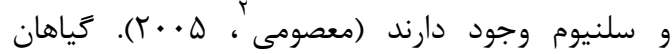

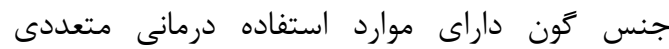

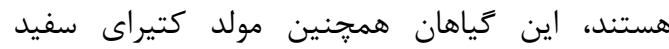

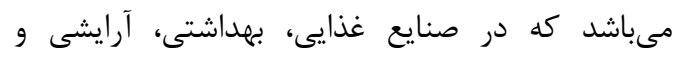
دارويى كاربرد دارد.

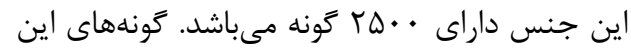
جنس در مناطق استيى، زيستعاههاى خشك و نيمه خشك در آمريكاى شمالى و جنوبى، آنى ارويا، آسيا و

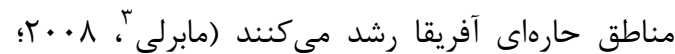

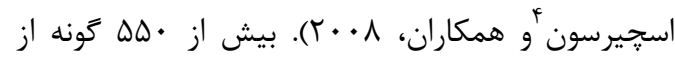
جنس گون در ايران رشد مى كنند (مظفريان ؛ 999 (1).

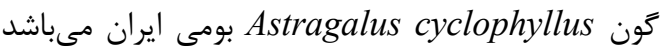

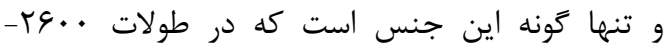

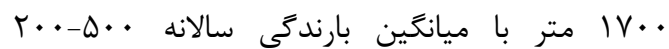

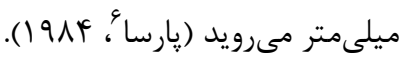
بديهى است كه حالت خواب در بذر براى گياهان

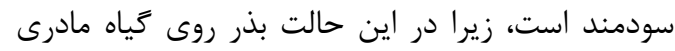
جوانه نخواهد زد و فرصت زيراكنش دارد. از سوى ديخر بذر در اين حالت غيرفعال است و در نتيجه بسيارى از تنشهاى محيطى و شرايط نامناسب اقليمى را بهتر

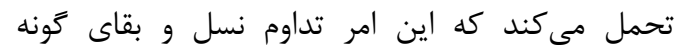

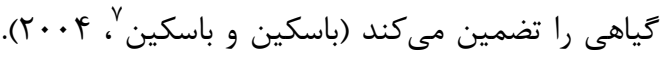

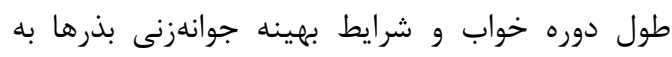
ساختار زنتيكى و شرايط اقليمى كه گياه مادرى از آن منشأ كرفته است، موقعيت بذر رونى روى كياه مادرى، لايه

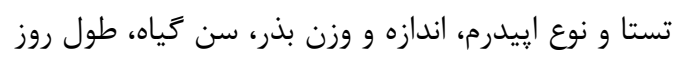

\footnotetext{
${ }^{1}$ Fabaceae

2 Masoumi

${ }^{3}$ Mabberley

${ }^{4}$ Scherson

${ }^{5}$ Mozaffarian

${ }^{6}$ Parsa

${ }^{7}$ Baskin and Baskin
} 
شد. فاكتور اول شامل سه اكوتيب سميرم (طول متوسط

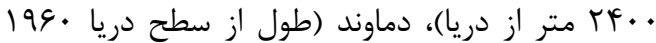

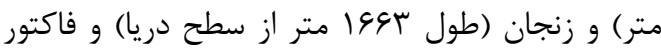
دوم شامل تيمارهاى شكست خواب بود. بذرهاى مورد

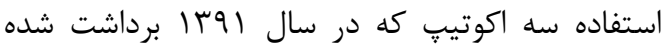

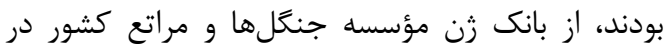
سال rوبا تهيه شدند. تيمارهاى اعمال شده عبارت بودند از: شاهد، خراشدهى مكانيكى (خراشدهى باديا

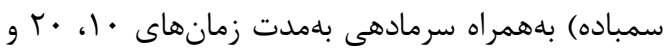

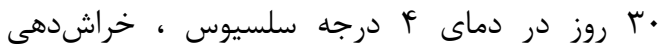

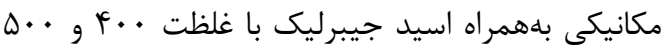
ميلى

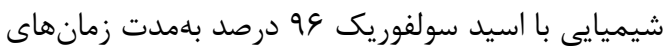

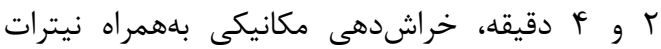
يتاسيم Y درصد بدمدت زمان VT ساعت، خراشدهى

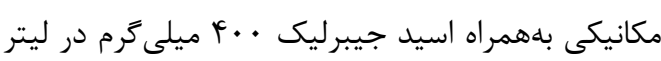

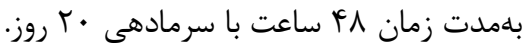

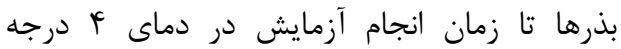

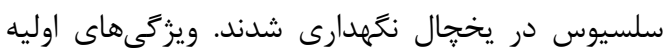
آنها شامل وزن هزار دانه، درصد خلوص فيزيكى، درصد

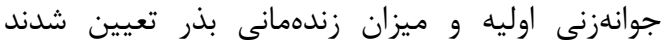
(جدول (). جهت ارزيابى ميزان زنده بودن بذر از آزمون

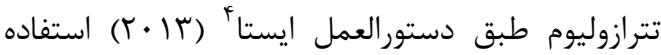
شد. قبل از شروع آزمايش جهت حذف بذرهاى يوك،

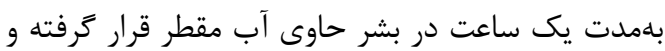
هر ها دقيقه هم زده شدند و در نهايت بذرهايى كه بعد بـد بلد از يك ساعت در سطح آب باقى ماندند، حذف شدند. جهت دقت بيشتر و به حداقل رساندن خطا تا حد إنداند ممكن بذرهايى انتخاب شدند كه از نظر اندازه يكنواخت

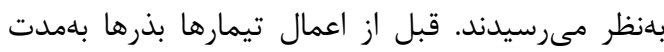
• 1 دقيقه با محلول هييوكلريت سديم 1 درصد

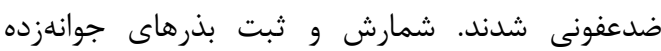

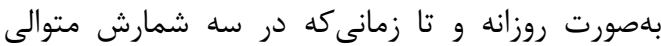

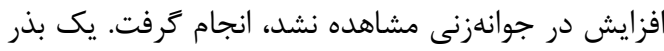

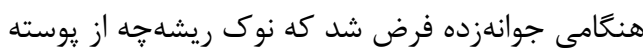

${ }^{4}$ ISTA
شدن خواب بذر و در نهايت افزايش درصد جوانهزنى مى گردد (باسكين و باسكين، (1991).

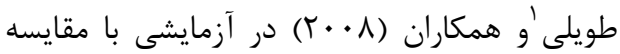
تأثير روشهاى مختلف شكست خواب بذر كياه دم كاوى

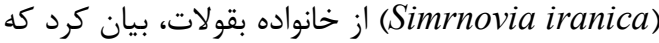
بيشترين ميزان جوانهزنى بذرها در اثر اعمال تيمار خراشدهى با كاغذ سمباده بهدست آمد. برايمينَ بذر بـر با اسيد جيبرليك نيز در شكست خواب گونههاى كياهى كه دجار خواب مىباشند مؤثر واقع شده و موجب جوانهزنى مىشود. اسيد جيبرليك باعث فعالسازى دئر متابوليسم، هضم مواد ذخيرهاى و انتقال به جنين، تقسيم و رشد سلولى شده و يديده جوانهزنى القا مىشود

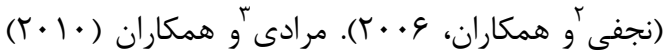

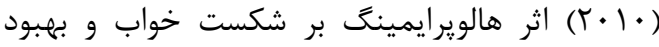
جوانهزنى بذر ارغوان (Cercis siliquastrum) را مورد

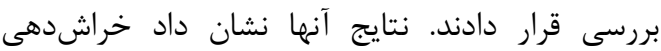

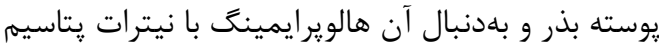
VD.

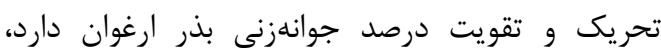
بلطورى كه سبب بهبود مشخصههاى جوانهزنى اين كونه

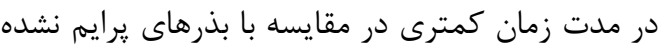

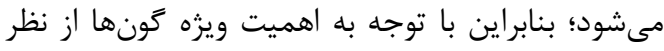
دارويى، علوفهاى و اقتصادى و گسترش وسيع آنها در كشور انجام بررسىهاى مختلف در زمينههاى شكست

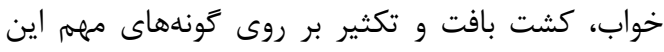
جنس بهخصوص كونههاى در حال انقراض حائز اهميت مىباشد. بدين منظور هدف از اين تحقيق بررسى إنى شكست خواب، جوانهزنى و يافتن مناسبترين تيمار جهت برطرف نمودن خواب بذر سه اكوتيب كون مرتعى

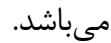

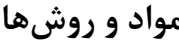

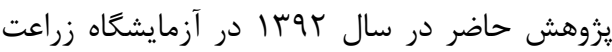
دانشكده كشاورزى دانشكاه لرستان بلصورت آزمايش فاكتوريل در قالب طرح كاملاً تصادفى با سه تكرار انجام إن إندان

${ }^{1}$ Tavili

${ }^{2}$ Najafi

${ }^{3}$ Moradi 
رستمى يور و همكاران: اثر تيمارهاى شكست خواب بر جوانهزنى و فعاليت آنزيم آلفا آميلاز بذر...

جدول ا. صفات اندازمخيرى شده بذر اكوتيبهاى سميرم، دماوند و زنجان

Table 1. Measured traits of the Seeds of Semirom, Damavand, and Zanjan Ecotypes.

\begin{tabular}{|c|c|c|c|}
\hline \multirow[b]{2}{*}{ صفات مورد بررسى } & \multicolumn{3}{|c|}{ اكوتيب Ecotype } \\
\hline & $\begin{array}{l}\text { سميرم } \\
\text { Semirom } \\
\end{array}$ & $\begin{array}{c}\text { د دماوند } \\
\text { Damavand }\end{array}$ & $\begin{array}{l}\text { j } \\
\text { Zanjan } \\
\end{array}$ \\
\hline $\begin{array}{c}\text { وزن هزار دانه (كرم) } 100 \text { grain weight (g) } \\
1000 \text {. }\end{array}$ & 4.18 & 4.32 & 4.11 \\
\hline $\begin{array}{c}\text { بنيه بذر (\%) } \\
\text { Vigor index (\%) }\end{array}$ & 84 & 91 & 90 \\
\hline $\begin{array}{c}\text { درصد جوانهزنى اوليه (/\%) } \\
\text { Primary germination percentage (\%) }\end{array}$ & 13 & 15 & 10 \\
\hline $\begin{array}{c}\text { (/) خلوص فيزيكى } \\
\text { Physical purity (\%) }\end{array}$ & 99 & 99 & 98.5 \\
\hline
\end{tabular}

ميلى ليتر بافر فسفات / / • مولار سرد با اسيديته V/T به بذرهاى يودر شده اضافه و به خوبى مخلوط شد و ورة

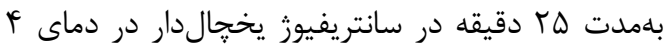

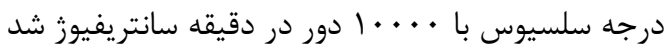
و بلافاصله محلول رويى جدا و تا زمان اندازهيرى

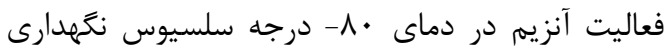
شد. فعاليت آلفا آميلاز در عصاره بذرها توسط روش

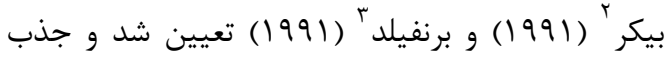

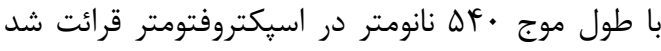
(فعاليت آنزيم بر اساس ميكرومول بر دقيقه بر بذر

$$
\text { مىباشد). }
$$

تجزيه و تحليل دادههاى بلهدست آمده با استفاده از نرمافزار آمارى SAS نسخه ميانگينها براساس آزمون دانكن در سطح احتمال هـ/ انجام گرفت.

نتايج و بحث درصد جوانهزنى كل

تجزيه واريانس دادهها نشان داد كه اثرات ساده اكوتي" (بجز وزن خشك گياهجه) و تيمارهاى شكست خواب بذر و اثر متقابل آنها بر همه صفات جوانهزنى در سطح يك درصد معنىدار شد (جدول ؟). مقايسه ميانگينها حاكى از اثر معنىدار اغلب تيمارها بر بهبود جوانهزنى بذر گَون بود (جدول س) و بيشترين درصد جوانهزنى مربوط به تيمار خراشدهى مكانيكى بههمراه

\footnotetext{
${ }^{2}$ Baker

${ }^{3}$ Bernfeld
}

بذر خارج شده بود (r ميلىمتر بر اساس استاندارد

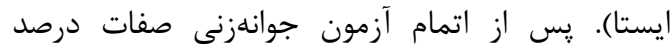
جوانهزنى، ميانگين زمان جوانهزنى، طول گياهجه، وزن

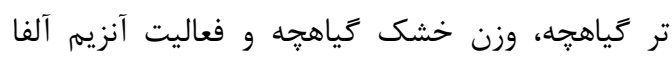
آميلاز مورد ارزيابى قرار كرفت. درصد جوانهزنى كل از وريان

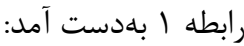
$\% \mathrm{GP}=\frac{n}{N} \times 1 \ldots$

كه دراين رابطه، Gp درصدجوانهزنى كل،n تعداد بذرهاى جوانه زده و N تعداد كل بذرهاىكشت شده مىباشند. اندازهزيرى فعاليت آنزيمى براى اندازهگيرى فعاليت آلفا آميلاز از بذرهاى

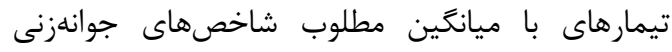
استفاده شد. بدين منظور، بذرهاى تيمار شده و تيمار

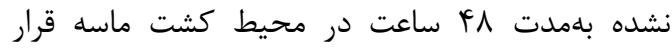
كرفتند تا فرايندهاى جوانهزنى در بذر آغاز شود. يس از

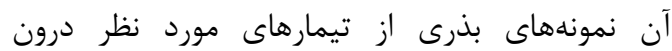
ميكروتيوت قرار گرفتند و بلافاصله درون نيتروزن مايع

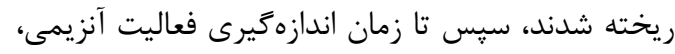

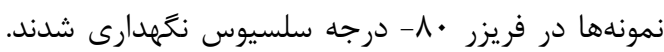

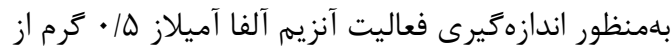

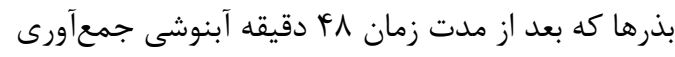
شده بودند در هاون سرد با نيتروزن مايع به خوبى يودر

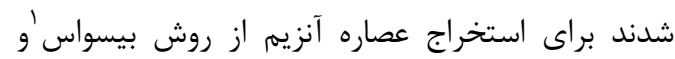

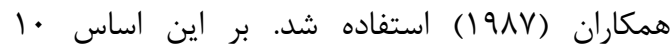

\footnotetext{
${ }^{1}$ Biswas
} 
جدول r. تجزيه واريانس تيمارهاى شكست خواب بذر براى برخى صفات جوانهزنى گون

Table 2. Analysis of variance for seed dormancy breaking treatments on some germination traits of Astragalus cyclophyllus

\begin{tabular}{|c|c|c|c|c|c|c|}
\hline $\begin{array}{l}\text { منابع تغيير } \\
\text { S.O.V }\end{array}$ & $\begin{array}{l}\text { آزادى درجه } \\
\text { df }\end{array}$ & $\begin{array}{c}\text { درصدجوانهزنى } 1 \text { كل } \\
\text { Total } \\
\text { germination } \\
\text { percentage }\end{array}$ & $\begin{array}{l}\text { ميانگين زمان جوانهزنى } \\
\text { Mean } \\
\text { germination time }\end{array}$ & $\begin{array}{l}\text { طول گياهجه } \\
\text { Seedling } \\
\text { height }\end{array}$ & $\begin{array}{l}\text { وزنترَياهجه } \\
\text { Seedling } \\
\text { fresh } \\
\text { weight }\end{array}$ & 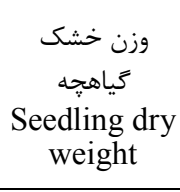 \\
\hline اكوتي؟ Ecotype (A) & 2 & $177.73^{\text {祘 }}$ & 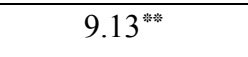 & $16.31 * *$ & $0.05 * *$ & $0.02^{\mathrm{ns}}$ \\
\hline $\begin{array}{l}\text { تيمارهاى شكست خواب بذر } \\
\text { Dormancy breaking } \\
\text { treatments (B) }\end{array}$ & 9 & $2635.90^{* * \%}$ & $24.08^{\text {w** }}$ & $1212.26 * *$ & $1.15 * *$ & $4.48 * *$ \\
\hline اكوتيب × تيمارهاى شكست & 18 & $381.38^{\text {**⿲二丨匕口 }}$ & $4.06^{\text {**: }}$ & $100.77 * *$ & $0.20 * *$ & $0.66^{\text {*** }}$ \\
\hline خطاى آزمايشى Error & 60 & 17.53 & 0.21 & 1.14 & 0.004 & 0.013 \\
\hline $\begin{array}{c}\text { ضريب تغييرات (درصد) } \\
\text { C.V. (\%) }\end{array}$ & - & 8.22 & 8.94 & 2.01 & 7.93 & 10.03 \\
\hline
\end{tabular}

**and ns., significant at $1 \%$ and not significant probability levels, respectively.

سميرم جوانهزنى بالاترى داشت. در هر سه اكوتيب اعمال تيمار خراشدهى با اسيد سولفوريك بهمدت زمان إندان

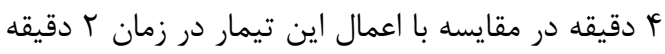

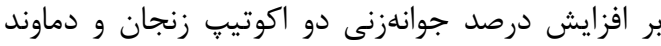

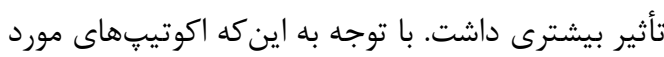

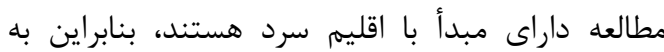
منظور افزايش جوانهزنى نياز به تيمار سرمادهى بيشتر از •ا روز دارند. بهنظر مىرسد بذر تونهائهاى رشد يافته در

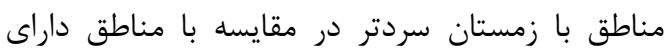
زمستان ملايم نياز به سرمادهى بيشترى دارند (وستوود

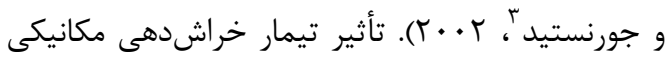

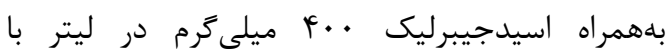
سرمادهى • · روز بر افزايش درصد جوانهزنى در برخى كونهاى كون مانند Astragalus cicer L.

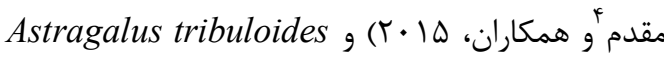

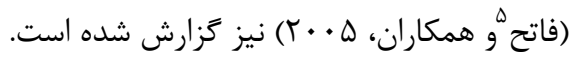

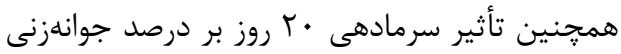
اكوتيب دماوند و زنجان نسبت به اكوتيٍ سميرم بيشتر

\footnotetext{
${ }^{3}$ Westwood and Jornstad

${ }^{4}$ Khayat Moghadam

${ }^{5}$ Fateh
}

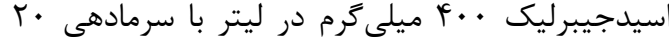
روز در اكوتيٍ سميرم با ميانگين N N I درصد بود. اين درحالى است كه كمترين جوانهزنى مربوط به بذرهاى

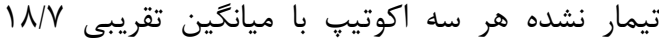

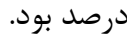

بذرهاى با خراشدهى مكانيكى بههمراه سرمادهى

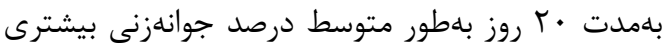
نسبت به اعمال همين تيمار با سرمادهى • • و •r روز

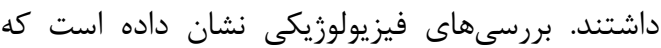
تيمار سرمادهى در مورد بذرها منجر به تغيير نسبت هورمونهاى درونى بذر به نفع اسيد جيبرليك، تغذيه

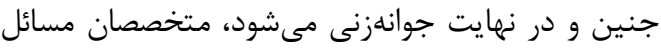
بذرى معتقدند كه اين هورمون مىتواند جانشين مناسبى براى برطرف نمودن نياز سرمايى بذر يا حتى فراتر از آن كليه عوامل مؤثر بر جوانهزنى بذر باشد

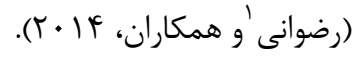
خراشدهى مكانيكى بdهمراه سرما و اسيد جيبرليك رنى

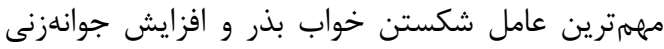

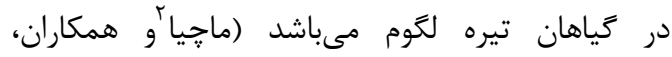

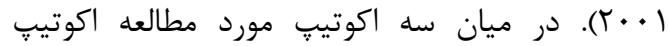

\footnotetext{
${ }^{1}$ Rezvani

${ }^{2}$ Macchia
} 
جدول r. مقايسه ميانكين برهمكنش اكوتيِ و تيمارهاى شكست خواب بذر براى برخى صفات جوانهزنى در گون (در هر ستون ميانكينها با

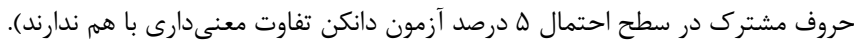

Table 3. Mean comparisons of amphidiarthrodial ecotype and seed dormancy breaking treatments on some germination traits of Astragalus cyclophyllus (in each column means having the same letter are not significantly different from each other according to Duncan 0.05).

\begin{tabular}{|c|c|c|c|c|c|c|}
\hline اكوتيب & تيمار شكست خواب & جوانهزنى (درصد) & جوانهزنين (روز) & 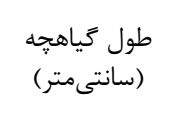 & 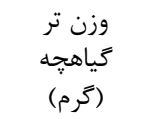 & كَياهجه خَرم) \\
\hline Ecotype & $\begin{array}{c}\text { Dormancy } \\
\text { breaking treatment }\end{array}$ & $\begin{array}{c}\text { Total } \\
\text { germination } \\
\text { percentage } \\
(\%) \\
\end{array}$ & $\begin{array}{c}\text { Mean } \\
\text { germination } \\
\text { time }(d)\end{array}$ & $\begin{array}{c}\text { Seedling } \\
\text { height }(\mathrm{cm})\end{array}$ & $\begin{array}{l}\text { Seedling } \\
\text { Fresh } \\
\text { weigh }(g)\end{array}$ & $\begin{array}{l}\text { Seedling } \\
\text { Dry weight } \\
\text { (g) }\end{array}$ \\
\hline \multirow{5}{*}{ سميرم } & $\mathrm{t} 1$ & $20 \mathrm{j}$ & $9.36 \mathrm{a}$ & $4.03 \mathrm{r}$ & 0.141 & 0.03 o \\
\hline & $\mathrm{t} 2$ & $20 \mathrm{j}$ & $8.44 \mathrm{~b}$ & $5.76 \mathrm{hi}$ & $0.4 \mathrm{k}$ & $0.04 \mathrm{n}$ \\
\hline & $\mathrm{t} 3$ & $64 f g$ & $4.61 \mathrm{gh}$ & $5.51 \mathrm{kl}$ & $1.15 \mathrm{~cd}$ & $0.14 \mathrm{~d}$ \\
\hline & $\mathrm{t} 4$ & $50.67 \mathrm{ef}$ & $7.46 \mathrm{c}$ & $5.89 \mathrm{gh}$ & $0.94 \mathrm{e}$ & $0.13 \mathrm{~d}$ \\
\hline & t5 & $54.67 \mathrm{e}$ & $4.21 \mathrm{hi}$ & $6.61 \mathrm{c}$ & $0.94 \mathrm{e}$ & $0.09 \mathrm{i}$ \\
\hline \multirow[t]{8}{*}{ Semirom } & t6 & $45.33 \mathrm{fg}$ & $4.67 \mathrm{gh}$ & $5.55 \mathrm{jk}$ & $0.59 \mathrm{hi}$ & $0.05 \mathrm{i}$ \\
\hline & $\mathrm{t} 7$ & $51.33 \mathrm{ef}$ & $3.19 \mathrm{jk}$ & $4.84 \mathrm{~m}$ & $0.62 \mathrm{gh}$ & $0.07 \mathrm{k}$ \\
\hline & t8 & $51.33 \mathrm{ef}$ & $4.01 \mathrm{hi}$ & $3.15 \mathrm{t}$ & $0.52 \mathrm{ij}$ & $0.09 \mathrm{i}$ \\
\hline & t9 & $50 \mathrm{ef}$ & $3.99 \mathrm{hi}$ & $6.89 \mathrm{~b}$ & $1.24 b c$ & $0.09 \mathrm{i}$ \\
\hline & $\mathrm{t} 10$ & $84.67 \mathrm{a}$ & $3.24 \mathrm{jk}$ & $4.62 \mathrm{n}$ & $1.49 \mathrm{a}$ & $0.37 \mathrm{a}$ \\
\hline & $\mathrm{t} 1$ & $18.33 \mathrm{j}$ & $8.26 b c$ & $3.98 \mathrm{r}$ & 0.141 & $0.03 \mathrm{o}$ \\
\hline & $\mathrm{t} 2$ & $18.67 \mathrm{j}$ & $5.33 \mathrm{ef}$ & 4.55 no & $0.39 \mathrm{k}$ & $0.04 \mathrm{n}$ \\
\hline & $\mathrm{t} 3$ & $70 b c$ & $6.09 \mathrm{de}$ & $6.57 \mathrm{c}$ & $1.33 \mathrm{~b}$ & $0.17 \mathrm{c}$ \\
\hline \multirow{2}{*}{ دماوند } & $\mathrm{t} 4$ & $66.67 \mathrm{bc}$ & $7.83 b c$ & $7.37 \mathrm{a}$ & $1.47 \mathrm{a}$ & $0.17 \mathrm{c}$ \\
\hline & t5 & $68 b c$ & $4.13 \mathrm{hi}$ & $7.04 \mathrm{a}$ & $1.44 \mathrm{a}$ & $0.14 \mathrm{~d}$ \\
\hline \multirow[t]{8}{*}{ Damavand } & t6 & $53.33 \mathrm{ef}$ & $6.28 \mathrm{~d}$ & 5.331 & $0.71 \mathrm{fg}$ & $0.08 \mathrm{i}$ \\
\hline & $\mathrm{t} 7$ & $52.67 \mathrm{ef}$ & $4.58 \mathrm{gh}$ & $4.27 \mathrm{pq}$ & $0.66 \mathrm{fg}$ & $0.07 \mathrm{j}$ \\
\hline & t8 & $72.33 b c$ & $1.9 \mathrm{~m}$ & $3.12 \mathrm{t}$ & $0.43 \mathrm{jk}$ & $0.08 \mathrm{i}$ \\
\hline & t9 & $49.33 \mathrm{ef}$ & $6.28 \mathrm{~d}$ & $6.34 \mathrm{~d}$ & $0.93 \mathrm{e}$ & $0.1 \mathrm{~h}$ \\
\hline & $\mathrm{t} 10$ & $67.33 b c$ & $4.76 \mathrm{gh}$ & $3.95 \mathrm{r}$ & $1.3 \mathrm{~b}$ & $0.28 \mathrm{~b}$ \\
\hline & $\mathrm{t} 1$ & $18 \mathrm{j}$ & $7.51 \mathrm{c}$ & 4.43 op & 0.171 & 0.04 no \\
\hline & $\mathrm{t} 2$ & $34.67 \mathrm{i}$ & $3.49 \mathrm{ij}$ & $6.23 \mathrm{de}$ & $0.69 \mathrm{fg}$ & $0.06 \mathrm{~lm}$ \\
\hline & $\mathrm{t} 3$ & $68 b c$ & $4.83 \mathrm{gh}$ & $6.01 \mathrm{fg}$ & $1.08 \mathrm{~d}$ & $0.27 \mathrm{~b}$ \\
\hline \multirow{2}{*}{ زنجان } & $\mathrm{t} 4$ & $53.33 \mathrm{ef}$ & $5.85 \mathrm{de}$ & $5.63 \mathrm{ij}$ & $0.67 \mathrm{fg}$ & $0.09 \mathrm{i}$ \\
\hline & t5 & $71.33 \mathrm{bc}$ & $3.43 \mathrm{ij}$ & $6.74 b c$ & $1.31 \mathrm{~b}$ & $0.13 \mathrm{e}$ \\
\hline \multirow[t]{5}{*}{ Zanjan } & t6 & $37.67 \mathrm{hi}$ & $4.81 \mathrm{gh}$ & $5.5 \mathrm{kl}$ & $0.67 \mathrm{fg}$ & $0.07 \mathrm{j}$ \\
\hline & $\mathrm{t} 7$ & $64.67 \mathrm{~cd}$ & $2.53 \mathrm{~lm}$ & $5.72 \mathrm{hi}$ & $1.13 \mathrm{~d}$ & $0.12 \mathrm{f}$ \\
\hline & t8 & $74 \mathrm{~b}$ & $4.48 \mathrm{gh}$ & $3.66 \mathrm{~s}$ & $0.74 \mathrm{f}$ & $0.11 \mathrm{gh}$ \\
\hline & t9 & $43.33 \mathrm{gh}$ & $5.24 \mathrm{fg}$ & $6.12 \mathrm{ef}$ & $1.07 \mathrm{~d}$ & $0.08 \mathrm{i}$ \\
\hline & 10 & $33.33 \mathrm{i}$ & $2.79 \mathrm{kl}$ & $4.12 \mathrm{qr}$ & $0.61 \mathrm{gh}$ & $0.15 \mathrm{~d}$ \\
\hline \multicolumn{7}{|c|}{ 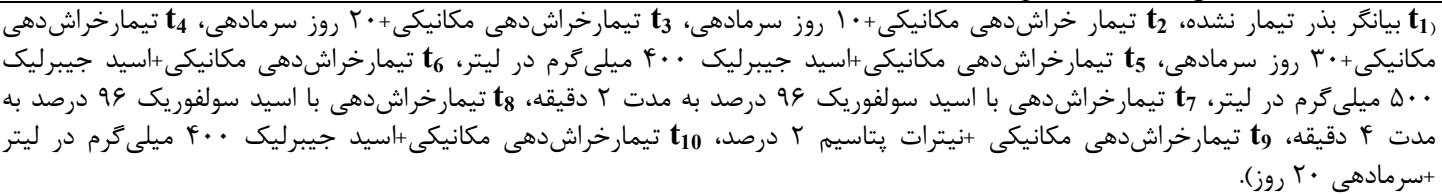 } \\
\hline
\end{tabular}

t1: Control, t2: Mechanical scarification+10 days stratification, t3: Mechanical scarification +20 days stratification, $\mathrm{t}$ : Mechanical scarification+30 days stratification, t5: Mechanical scarification + gibberellic acid $400 \mathrm{mg} /$ liter, t6: Mechanical scarification + gibberellic acid $500 \mathrm{mg} / \mathrm{liter}, \mathrm{t} 7$ : Scarification with sulfuric acid $96 \%$ for 2 minutes, t8: Scarification with sulfuric acid 96\% for 4 minutes, t9: Mechanical scarification $+2 \%$ potassium nitrate, t10: Mechanical scarification + gibberellic acid $400 \mathrm{mg} /$ liter+20 days stratification).

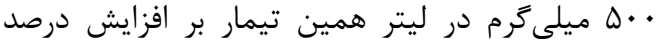

جوانهزنى اكوتيڤ دماوند و زنجان با ميانگين
تيمار خراشدهى مكانيكى بلهمراه اسيد جيبرليك

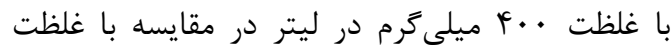


سانتىمتر بود. اختلاف طول كياهجه در اكوتيب زنجان

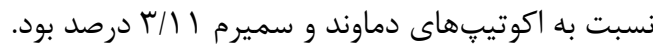
در خراشدهى مكانيكى بههمراه سرما، خراشدهى مكانيكى بيشترين تأثير را در توليد كياهجههاى بهاى عادى داشت، در صورتى كه سرما نسبت مواد تحريك كنينده

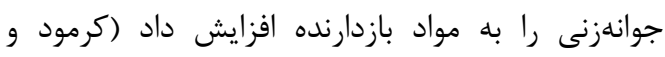

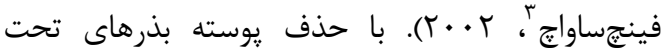

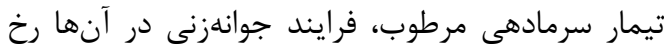

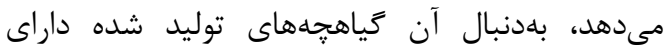
ميانكَرهاى بلند و رشد سريع خواهند بود. همجنين كاربرد اسيد جيبرليك باعث افزايش طول ميانكرهها و در

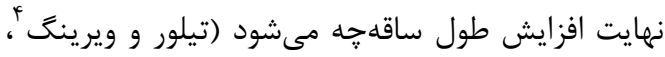

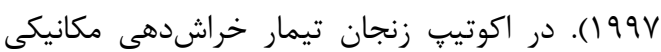

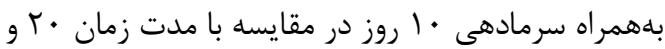

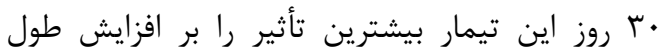

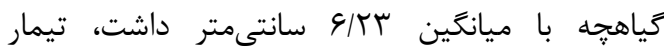
خراشدهى بههمراه اسيد جيبرليك . . . ميلى كرم در

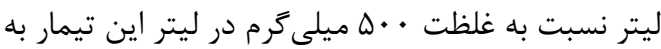

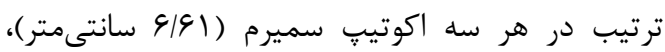

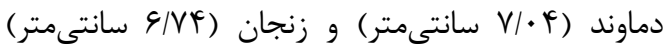

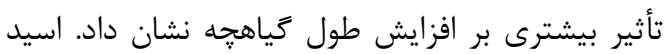

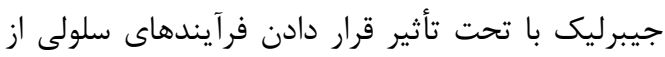
جمله تحريك تقسيم سلولى و طويل شدن سلولها سبب افزايش رشد رويشى مى كردد. اسيد جيبرليك با افزايش كشش ديواره سلولى يعنى انبساط ديو ديواره از ردئ طريق هيدروليز نشاسته به قند كه كاهش يتانسيل آب آب آبساط سلول را بهدنبال دارد، سبب ورود آب به درون سلول و

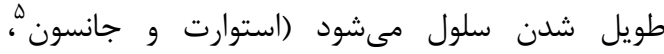

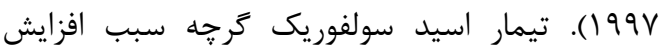
درصد جوانهزنى گرديد، اما اثرات مضر آن نيز بالا بوده بلهورى كه مدت زمان f أ دقيقه اين تيمار بيشترين

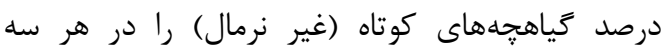
اكوتيت با ميانگين آس/ץ سانتىمتر ايجاد كرد، اما تيمار

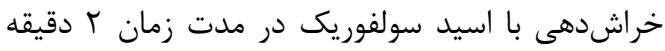

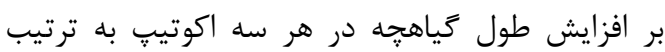

\footnotetext{
${ }^{3}$ Kermod and Finch-Savage

${ }^{4}$ Taylor and Wearing

${ }^{5}$ Stuart and Jones
}

درصد بيشترين تأثير را داشت. در دماى پايين اكسيثن بيشترى در آب حل مىشود، بنابراين نيازهاى اكسيرنى داني

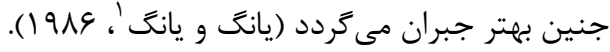
ميانغين زمان جوانهزنى (مانى ميانكَين زمان جوانهزنى (معادل 9 روز) در بذرهان تيمار نشده اكوتيب سميرم بالاترين مقدار بود و كمترين

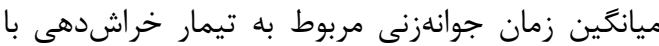
اسيد سولفوريك بهمدت زمان F د دقيقه (معادل Y ر روز)

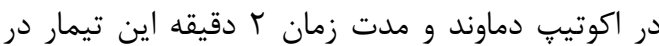

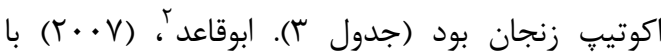

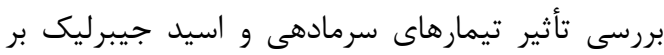
P. ، برهاى سه كونه بنه (Pistacia atlantic Desf.) (P. lentiscus L. و نشان دادند كه شاخص ميانكين زمان جوانهزنى تحت تيمار سرمادهى و اسيد جيبرليك كاهش يافت. با توجه به نانه

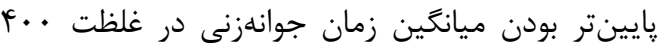

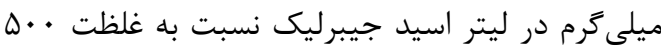

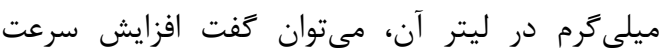
جوانهزنى بذرهاى تيمار شده با اسيد جيبرليك ممكن است از طريق كوتاه كردن مدت زمان سوخت و و ساز باعث تسريع جوانهزنى شده و به دنبال آن منجر به كاهش ميانكين زمان جوانهزنى شود (باسكين و باسكين،

$$
\text { (r... }
$$

\section{طول كياهجه}

مقايسه ميانكين دادها (جدول r) نشان داد كه

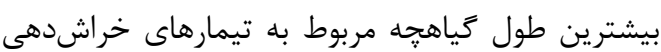
مكانيكى بههمراه سرمادهى •r روز در اكوتيب دماوند و

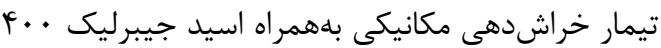

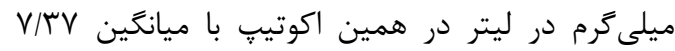

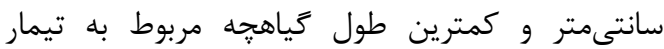

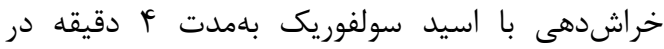

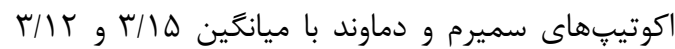

\footnotetext{
${ }^{1}$ Young and Young

${ }^{2}$ Abu-Qaoud.
} 
وزن تر كياهجه تأثير بلهزايى داشته باشند (جايورون'

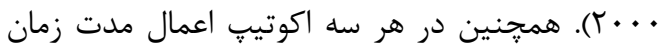

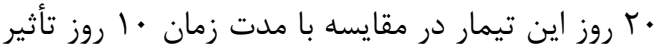

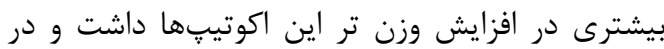

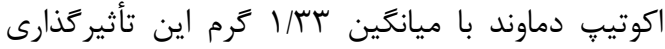
بيشتر بود. در هر سه اكوتيب تأثير تيمار اسيد

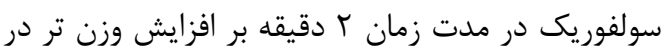

$$
\text { مقايسه با مدت زمان \& ل دقيقه بيشتر بود. }
$$

\section{وزن خشك تياهجه}

مطابق نتايج مقايسه ميانكين (جدول بان) بيشترين ميزان

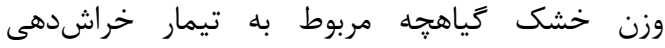

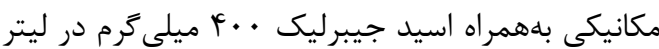

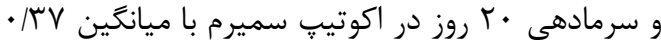

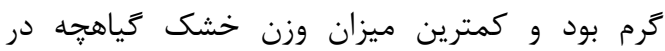
بذرهاى تيمار نشده اكوتيبهاى سميرم، دماوند و زنجان

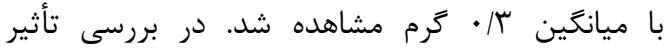
غلظتهاى مختلف اسيد جيبرليك و مدت زمان زمانهاى سرمادهى بر جوانهزنى بذر انجير (Ficus carica L.) كزارش شده است كه تيمار اسيد جيبرليك با غلظتهاى

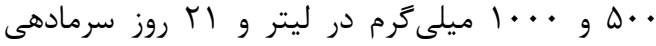

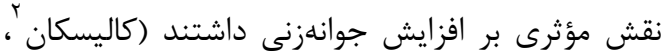

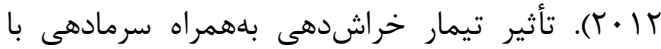

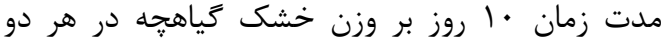
اكوتيت سميرم و دماوند يكسان و به اندازه بذرهاى

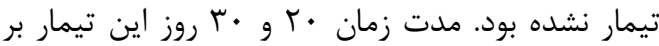
افزايش وزن خشك كياهجه دو اكوتيب سميرم و دماوند

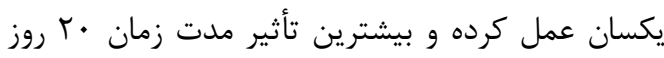
اين تيمار بر افزايش وزن خشك كياهجه اكوتيب زنجان

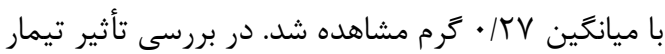

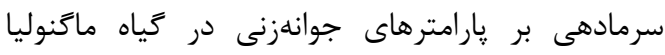
مشخص شد كه تيمار (Magnolia grandiflora L.)

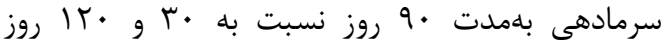
بيشترين وزن خشك گياهجه در اين كياه را به دنبال

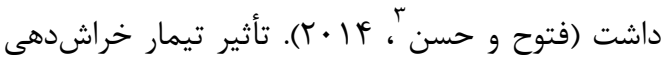

${ }^{1}$.Jauron

${ }^{2}$ Caliskan

${ }^{3}$ Fotooh and Hasan

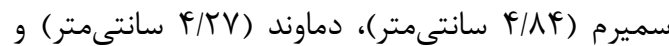
زنجان (D/VT سانتىمتر) مؤثرتر بود. دليل اين امر به بهاديه

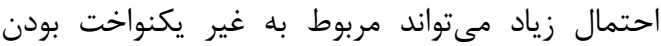

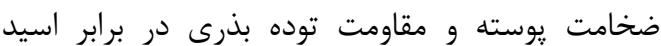
باشد؛ زيرا جنين تودههاى بذرى از نظر خصوصيات كنترل كننده خواب، غير يكنواخت هستند. اخر مدت

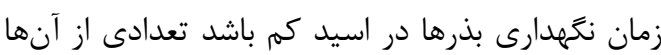
جذب آب نخواهند داشت و اكر مدت افزايش يابد، جنين بذرهايى كه داراى يوسته ضعيفترى هستند خسارت

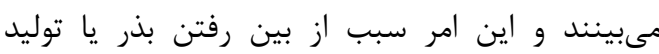

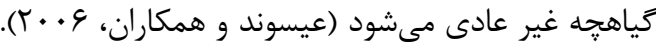

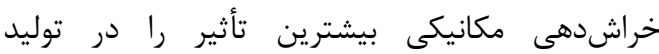
كياهجههاى عادى داشت، خراشدهى مكاني مكانيكى اثرات نامطلوبى روى جنين و ساختار بذر وارد نمى كند و به دليل نزديكى بيشترى كه به شرايط طبيعى دارد، براى

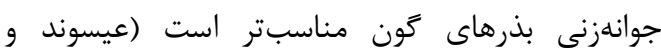

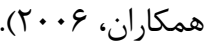

وزن تر گياهجه

همانطور كه نتايج مقايسه ميانگين (جدول ؟) نشان داد تيمار خراشدهى مكانيكى بههمراه اسيد

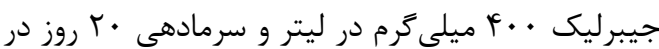

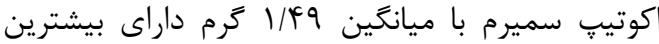

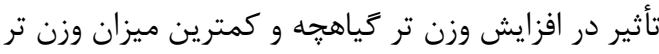

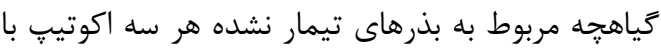

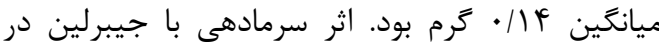
بذرهايى كه در نهايت جوانهزنى در آنها صورت مي كيرد

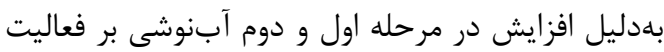
آنزيم تجزيه كنندهى ذخاير غذايى در بذر و سوخت و ورائ

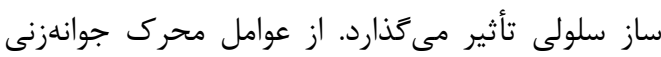

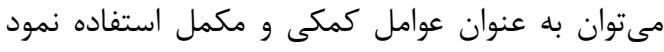
زيرا فرايند جوانهزنى بذرهاى داراى يوشش سخت نتيجه اثر متقابل مجموعهاى از عوامل درونى و بيرونى

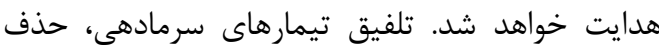
يوسته بذر و بهكاركيرى هورمونهاى محرك مى توانند از طريق تأثير بر رشد كياهجه در افزايش وزن خشك 


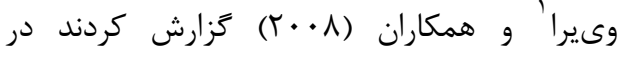
بذرهايى كه داراى خواب زياد هستند به دليل عدم تعادل دو هورمون اسيد آبسيزيك و اسيد جيبرليك به به به به

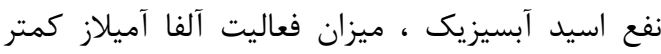

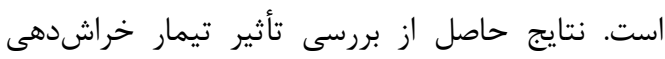

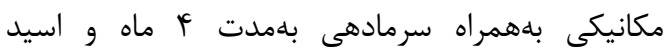

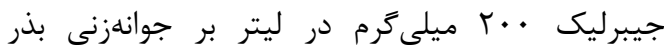
سرخدار (Taxus chinensis) نشان داد كه فعاليت آنزيم آلفا آميلاز بعد از اعمال اين تيمار افزايش

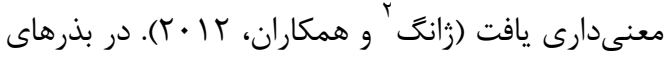
مرزنكوش (Origanum vulgar) فعاليت آنزيم آلفا آميلاز از • r درصد در بذرهاى تيمار نشده به هو درصد در بذرهاى تيمار شده با سرمادهى بهمدت ل V روز و اسيد

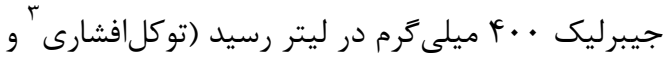

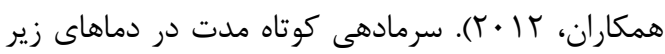
صفر بهعنوان يك شوك سرمايى به بذر است تا علاوه بر

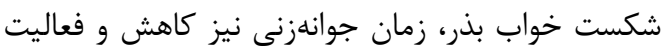

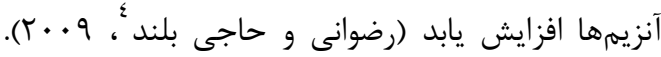

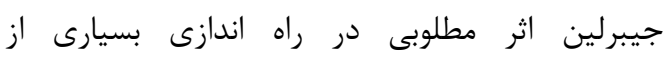
واكنشهاى آنزيمى مربوط به جوانهزنى دارد (ال -

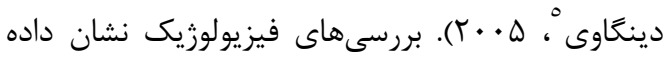

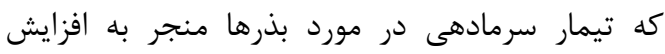

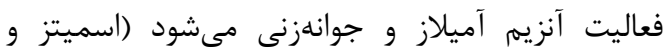

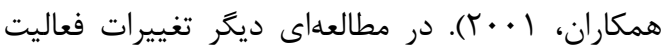

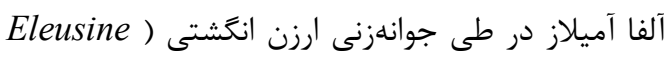
نشان داد كه فعاليت آنزيم آلفا آميلاز در آنسئ (coracana بذرهاى تيمارشده با اسيد جيبرليك نسبت به شاهد

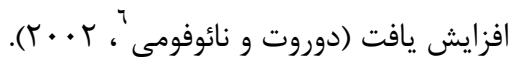

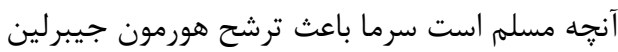

در بذر شده و با افزايش اين هورمون ميزان اسيد آبسيزيك كاهش مىيابد. سيس اسيد جيبرليك به لايه آلورون رفته و آنزيمهاى مختلفى را فعال ميى كند. يكى از

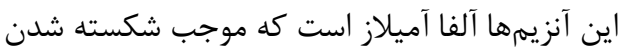

\footnotetext{
${ }^{1}$ Vieira

2 Zhang

${ }^{3}$ Tavakol-Afshari

${ }^{4}$ Razavi and Hajiboland

${ }^{5}$ El-Dengawy

${ }^{6}$ Doroth and Naofumi
}

مكانيكى بdهمراه اسيد جيبرليك با غلظت ع. F. ميلى گرم در ليتر نسبت به غلظت · له ميلى گرم در ليتر

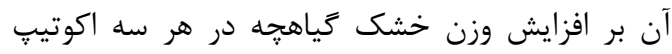
بيشتر بود. تيمار خراشدهى با اسيد سولفوريك در هر

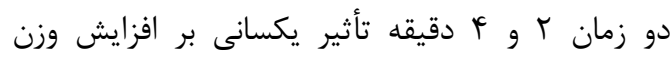
خشك گياهجه در هر سه اكوتيب نشان داد.

\section{فعاليت آنزيم آلفا آميلاز}

نتايج حاصل از جدول تجزيه واريانس حاكى از تأثير معنى دار برهمكنش اكوتيتٍ و تيمارهاى شكست خواب بذر بر فعاليت آنزيم آلفا آميلاز در سطح يك درئي دردد بود

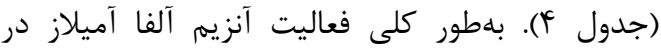
بذرهاى تيمار شده افزيش پيدا كرد. مطابق نتايج

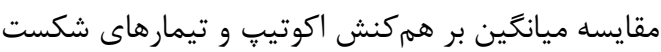
خواب بذر (جدول ه) بيشترين ميزان فعاليت اين آنزيم مربوط به تيمار خراشدهى مكانيكى بهاضافه اسيد

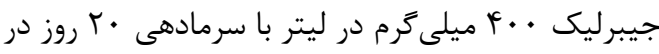
اكوتيتٍ سميرم به ميزان وزن تر بذر و كمترين فعاليت آنزيم آلفا آميلاز مربوط به بذرهاى تيمار نشده اكوتيڤٍاى زنجان با ميانخين ميكرومول بر ميلى

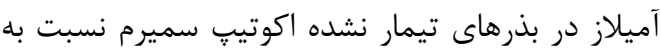
اكوتيڤهاى دماوند و زنجان بيشتر بود. تأثير تيمار

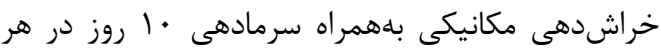
سه اكوتيبٍ از لحاظ فعاليت آنزيم آلفا آميلاز نسبت به به به ديگر تيمارهاى اعمال شده كمتر بود. تيمار خراشدهى

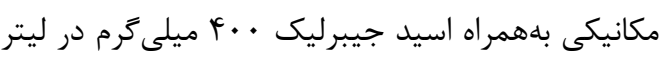
بيشترين تأثير را بر افزايش فعاليت آنزيم آلفا آميلاز در بذرهاى اكوتيب دماوند بر جاى حذاشت و تأثير آن در دو اكوتيب ديخر به يك اندازه بود. فعاليت آنزيم آلفا آميلاز

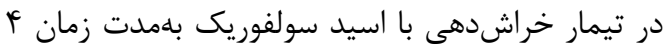
دقيقه در دو اكوتيب زنجان و سميرم به يك اندازه افزايش يافت. با توجه به بررسى ميزان فعاليت اين آنزيم

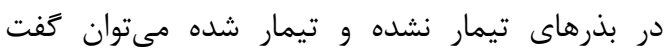

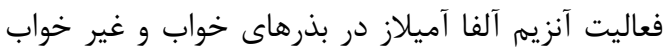
كه آبنوشى كرده بودند، افزايش داشت. 
جدول F. تجزيه واريانس تيمارهاى شكست خواب بذر بر فعاليت آنزيم آلفا آميلاز در كون

Table 4. Analysis of variance of seed dormancy breaking treatments on the activity of $\alpha$-amylase in the Astragalus cyclophyllus.

\begin{tabular}{|c|c|c|}
\hline $\begin{array}{l}\text { S.O.V } \\
\text { S.O.V }\end{array}$ & درجه آزادى Df & $\begin{array}{c}\text { آلفا آميلاز } \\
\alpha \text {-amylase }\end{array}$ \\
\hline $\begin{array}{c}\text { اكوتيتِ } \\
\text { Ecotype (A) }\end{array}$ & 2 & $43.54^{* * *}$ \\
\hline $\begin{array}{c}\text { تيمارهاى شكست خواب بذر Dormancy breaking treatments (B) } \\
\text { Dكاى }\end{array}$ & 5 & $69.24^{* * *}$ \\
\hline اكوتيب × تيمارهاى شكست خواب بذر A A & 10 & $52.06^{\text {***a }}$ \\
\hline خطاى آزمايشى Error & 36 & 0.22 \\
\hline $\begin{array}{c}\text { ضريب تغييرات (درصد) } \\
\text { C.V. (\%) }\end{array}$ & - & 5.95 \\
\hline
\end{tabular}

**significant at $1 \%$ probability level

كون بايستى سختى و نفوذنايذيرى يوسته بذر توسط

تيمارهاى خراشدهى مكانيكى يا شيميايى رفع شود و

جنين استنباط مىشود كه خواب بذر اين گَونه گياهى از

نوع فيزيكى مىباشد زيرا با حذف يوسته بذرها قادر به

$$
\text { جوانهزنى خواهند بود. }
$$

$$
\text { تشكر و قدردانى }
$$

از همكارى مسئولين محترم آزمايشگاه زراعت و و

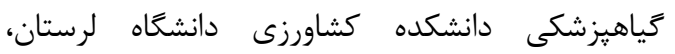

دانشعاه ياسوج و تمامى كسانى كه بلنحوى در يُشيشبرد

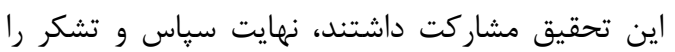

$$
\text { داريم. }
$$

قندها و نشاسته بذر شده و آنها را به مواد قابل استفاده جنين تبديل مى كند.

آميلازها نشاسته را هيدروليز و قندهاى لازم براى

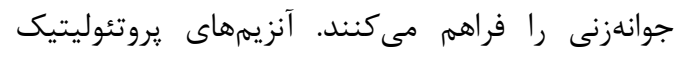
بههمراه سلولازها در تخريب ديواره سلولى به كار مىروند كه اولين كام ضرورى براى سست كردن يوسته قبل از خروج ريشهجه است (كايلند و مكدونالد '، ه99 (1).

نتيجه گيرى

نتايج آزمايش نشان داد كه تيمار خراشدهي باد اسيد

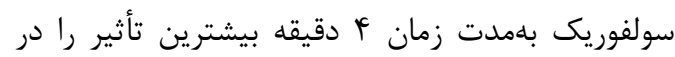

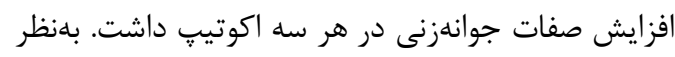
مىرسد خواب بذر گون از نوع فيزيولوزيك نباشد و تيمار خراشدهى مكانيكى بههمراه اسيد جيبرليك با غلظت

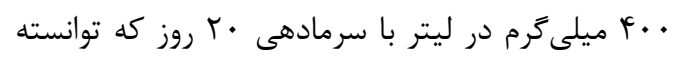

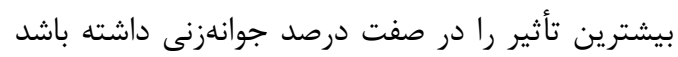

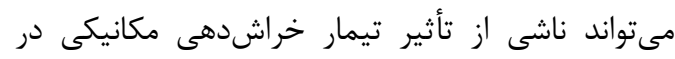
شكست خواب بهعلاوه اثر يرايمينگ دو عامل سرما و

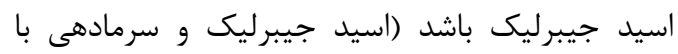
بهبود قوه ناميه بذر و افزايش كيفيت فيزيولوزيكى با طولانى كردن مرحله اول و دوم آبنوشى سبب شده تامئ بد فعاليتهاى آنزيمى بهخوبى صورت گرفته و در در نهايت منجر به افزايش جوانهنى گردد). براى جوانهزنى بذر برد

\footnotetext{
${ }^{1}$ Copeland and McDonald
} 
جدول ه. مقايسه ميانكَين برهم كنش اكوتيت و تيمار هاى شكست خواب بذر براى فعاليت آنزيم آلفا آميلاز در كون (ميانكَينها با حروف مشترى

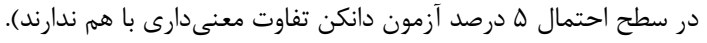

Table 5. Mean comparisons of amphidiarthrodial ecotype and seed dormancy breaking treatments for $\alpha$ amylase enzyme activity of Astragalus cyclophyllus (means having the same letter are not significantly different from each other according to Duncan 0.05).

\begin{tabular}{|c|c|c|}
\hline 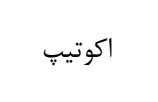 & 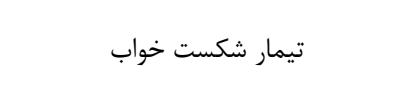 & 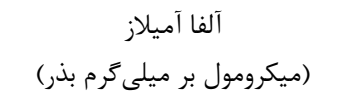 \\
\hline Ecotype & Dormancy breaking treatment & $\alpha$-amylase $(\mu \mathrm{m} / \mathrm{mg}$ seed $)$ \\
\hline \multirow{3}{*}{ 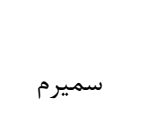 } & $\mathrm{t} 1$ & $7.13 \mathrm{e}$ \\
\hline & $\mathrm{t} 2$ & $6.51 \mathrm{f}$ \\
\hline & t5 & $7.83 d$ \\
\hline \multirow[t]{4}{*}{ Semirom } & t8 & $8.11 \mathrm{~d}$ \\
\hline & $\mathrm{t} 10$ & $23.99 \mathrm{a}$ \\
\hline & $\mathrm{t} 11$ & $5.42 \mathrm{~h}$ \\
\hline & $\mathrm{t} 1$ & $5.59 \mathrm{~h}$ \\
\hline \multirow{2}{*}{ 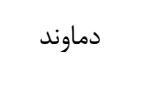 } & $\mathrm{t} 2$ & $5.55 \mathrm{~h}$ \\
\hline & $\mathrm{t} 5$ & $10.87 \mathrm{~b}$ \\
\hline \multirow[t]{4}{*}{ Damavand } & t8 & $9.5 \mathrm{c}$ \\
\hline & $\mathrm{t} 10$ & $9.05 \mathrm{c}$ \\
\hline & $\mathrm{t} 11$ & $8.13 d$ \\
\hline & $\mathrm{t} 1$ & $4.76 \mathrm{i}$ \\
\hline \multirow{2}{*}{ زنجان } & $\mathrm{t} 2$ & $5.63 \mathrm{~h}$ \\
\hline & $\mathrm{t} 5$ & $7.61 \mathrm{~d}$ \\
\hline \multirow[t]{3}{*}{ Zanjan } & t8 & $7.28 \mathrm{~d}$ \\
\hline & $\mathrm{t} 10$ & $6 \mathrm{~g}$ \\
\hline & $\mathrm{t} 11$ & $5.14 \mathrm{~h}$ \\
\hline
\end{tabular}

t

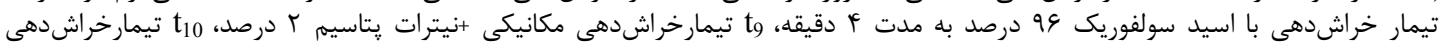

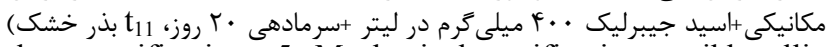

(t1: Control, t2: Mechanical scarification+10 days stratification, t5: Mechanical scarification + gibberellic acid $400 \mathrm{mg} /$ liter, t8: Scarification with sulfuric acid $96 \%$ for 4 minutes, t9: Mechanical scarification $+2 \%$ potassium nitrate, t10: Mechanical scarification + gibberellic acid $400 \mathrm{mg} /$ liter +20 days stratification, t11: Dry seed).

\section{منابع}

Abu-Qaoud, H. 2007. Effect of scarification, gibberellic acid and stratification on seed germination of three Pistacia species. Research Natural Science, 21:2-11.

Baker, J.E. 1991. Purification and partial characterization of Alpha-amylase Allozyme from the lesser grain borer Rhyzopertha dominica. Insect Biochemistry, 21: 303-311. https://doi.org/10.1016/0020-1790(91)90020-F

Balouchi, H.R. and Modarres Sanavy, S.A.M. 2006. Effect of gibberellic acid, prechilling, sulfuric acid and potassium nitrate on seed germination and dormancy of annual Medics. Pakistan Journal of Biological Sciences, 9 (15): 2875-2880. https://doi.org/10.3923/pjbs.2006.2875.2880

Baskin, C.C. and Baskin, J.M. 1998. Seeds Ecology, Biogeography, Evolution of Dormancy and Germination. Academic Press. San Diego. CA, USA: Academic Press. 
Baskin, J.M. and Baskin, C.C. 2004. A classification system for seed dormancy. Seed Science Research, 14:1-16. https://doi.org/10.1079/SSR2003150

Bernfeld, P. 1991. Amylase $\alpha$ and $\beta$. Methods in Enzymology, 1: 149-151.

Bewley, D.J., and Black, M. 1985. Seeds Physiology of Development and Germination. Plenum Press. New York, 445p. https://doi.org/10.1007/978-1-4615-1747-4

Bewley, J.D. 1997. Seed germination and dormancy. The Plant Cell, 9: 1055-1066. https://doi.org/10.1105/tpc.9.7.1055

Biswas, P.K., Devi, A., Roy, P.K. and Paul, K.B. 1987. Enzyme activity in dormant and nondormant larg crabgrass (Digitaria sanguinalis) seeds following hydration. Weed Science, 26(1): 90-93. https://doi.org/10.1017/S0043174500032744

Caliskan, O., Maviand K. and Polat, A. 2012. Influences of presowing treatments on the germination and emergence of fig seeds (Ficus carica L.). Acta Scientiarum Agronomy, 34(3): 294-297. https://doi.org/10.4025/actasciagron.v34i3.13392

Copeland, L.O. and McDonald, M.B. 1995. Principals of seed science and technology. Third Edition.Chapman and Hall. New York. 236p.

Doroth, M. and Naofumi, K. 2002. Changes in alpha- and Beta-amylase activities during seed germination of African finger millet. Food Science and Biotechnology, 52(6): 481-488. https://doi.org/10.1080/09637480220164361

Eisvand, H.R., Arefi, H.M. and Tavakol-Afshari, R. 2006. Effects of various treatments of breaking seed dormancy of Astragalus siliquosus. Seed Science and Technology, 34(3): 747-752. https://doi.org/10.15258/sst.2006.34.3.22

El-Dengawy, E.F.A. 2005. Promotion of seed germination and subsequent seedling growth of loaquat (Eriobotrya japonica) by moist-chilling GA3 applications. Scientia Horticulturae, 105(3): 331-342. https://doi.org/10.1016/j.scienta.2005.01.027

Fateh, E., Majnoonhosseini, N., Arefi, H.M. and Sharif-Zadeh, F. 2005. Seed dormancy methods breakage in Astragalus tribuloides. Iranian Journal of Rangelands and Forests Plant Breeding and Genetic Research, 13(4): 345-360 [In Persian with English Summary].

Fetouh, M. I. and Hassan, F.A. 2014. Seed germination criteria and seedling characteristics of Magnolia grandiflora L. trees after cold stratification treatments. International Journal of Current Microbiology and Applied Sciences, 3(3): 235-241.

Finch-Savage, W.E. and Leubner-Metzger, G. 2006. Seed dormancy and the control of germination. New Phytologist, 171(3): 501-523. https://doi.org/10.1111/j.14698137.2006.01787.x

Frey A., Godin, B., Bonnet, M., Sotta, B. and Marion-Poll, A. 2004. Maternal synthesis of abscisic acid control seed development and yield in Nicotiana plumbaginafolia. Planta, 218(6): 958-964. https://doi.org/10.1007/s00425-003-1180-7

Gupta,V. 2003. Seed germination and dormancy breaking techniques for indigenous medicinal and aromatic plants. Journal of Medicinal and Aromatic Plant Science, 25: 402-407.

Harberd, N.P. and Peng, J. 2002. The role of GA-mediated signaling in the control of germination. Weed Science, 5: 376-381. https://doi.org/10.1016/S1369-5266(02)00279-0

International Seed Testing Association. 2013. Guide to ISTA-Association overview [Electronic] Basserdorf: ISTA secretariat, [brochure] Access. http://www.Seed test.Org/upload/cms/user/ Guide to ISTA new web.

Jauron, R. 2000. Germination of tree seed, maples (Acer species). Department of Horticulture Iowa State University. 102-103. 
Kermod, A.R. and Finch-Savage, B.E. 2002. In: Black, M., Pritchard, H.W. (eds.). Desiccation and survival in plants: Drying without Dying. Wallingford: CABI, PP: 149-184.

Khayat Moghadam, M., Agah F. and Sadrabadi Haghighi, R. 2015. Evaluation of seed dormancy breaking methods in Astragalus parrowianus. International Journal of Farming and Allied Sciences, 4(5): 473-476.

Mabberley, D.J. 2008. Mabberley's Plant-Book. A Portable Dictionary of Plants, Their Classification and Uses, 3rd ed. Cambridge University Press, Cambridge.

Macchia, M., Angelini, L.G. and Ceccarini, L. 2001. Methods to overcome seed dormancy in Echinacea angustifolia DC. Scientia Horticulturae, 89(4): 317-324. https://doi.org/10.1016/S0304-4238(00)00268-5

Martin, I. and De la Cuadra, C. 2004. Evaluation of different scarification methods to remove hardseededness in Trifolium subterraneum and Medicago polymorpha accessions of the Spanish base genebank. Seed Science Technology, 32(3): 671-681. https://doi.org/10.15258/sst.2004.32.3.03

Masoumi, A. 2005. Astragalus of Iran. Tehran: Research Institute of Forests and Rangelands of Iran, V: 5-1. [In Persian].

Mc Donald, M.B. and Kwong, F.Y. 2005. Flower seeds longevity and deterioration. Flower seeds biology and technology. CABI Publishing, 187. https://doi.org/10.1079/9780851999067.0000

Moradi, A., Sharifzadeh, F., Tavakol Afshari R. and Maali Amiri, R. 2010. Seed priming effects on germination and seedling growth of tall wheat grass (Agropyron elongatum) under control and drought stress conditions. Journal of Rangeland, 4(3): 462-473. [In Persian with English Summary].

Mozaffarian, V.1996. A Dictionary of Iranian Plants Names, Farhang-e Moaser, Tehran, 228-230. [In Persian].

Najafi, F., Bannayan, M., Tabrizi, L. and Rastgoo, M. 2006. Seed germination and dormancy breaking techniques for Ferula gummosa and Teucrium polium. Journal of Arid Environment, 64: 542-547. https://doi.org/10.1016/j.jaridenv.2005.06.009

Parsa, A. 1984. Flora of Iran. Publisher Tehran University, 2: 801-905. [In Persian].

Razavi, S.M. and Hajiboland, R. 2009. Dormancy breaking and germination of Prangos ferulacea seeds. Journal of Biosciences (Eur Asian), 3: 78-83. https://doi.org/10.5053/ejobios.2009.3.0.11

Rezvani, M., Zaefarian, F. and Amini, V. 2014. Effects of chemical treatments and environmental factors on seed dormancy and germination of shepherds purse (Capsella bursa-pastoris L.) Medic.). Acta Botanica Brasilica, 28(4): 495-501. https://doi.org/10.1590/0102$33062014 a b b 3337$

Scherson, R.A., Vidal, R. and Sanderson, M.J.U. 2008. Phylogeny, biogeography, and rates of diversification of New World Astragalus (Leguminosae) with an emphasis on South American radiations. American Journal of Botany, 95: 1030-1039. https://doi.org/10.3732/ajb.0800017

Schmitz, N., Xia, J.H. and Kermode, A.R. 2001. Dormancy of yellow cedar seeds is terminated by gibberellic acid in combination with fluridone or with osmotic priming and moist chilling. Seed Science and Technology, 29: 331-346.

Schmitz, O., Krivan, V. and Ovadia, O. 2007.Trophic cascades: the primacy of trait-mediated indirect interactions. Ecology Letters, 7(2): 153-163. https://doi.org/10.1111/j.14610248.2003.00560.x

Segura, F., Vicente, M.J., Franco, J.A. and Martínez-Sanchez, J.J. 2015. Effects of maternal environmental factors on physical dormancy of Astragalus nitidiflorus (Fabaceae), a critically endangered species of SE Spain. Flora, 216: 71-76. https://doi.org/10.1016/j.flora.2015.09.001 
Stuart, D.I. and Jones, R.L. 1997. Roles of extensibility and trugor in gibberellins-and darkstimulated growth. Plant Physiology, 59: 61-68. https://doi.org/10.1104/pp.59.1.61

Tavakol-Afshari, R., Sharifzadeh, F. and Chavoshinasab, S. 2012. Germination improvement and $\alpha$-amylase and $\beta$-1,3-glucanase activity in dormant and non-dormant seeds of Oregano (Origanum vulgare). Australian Journal of Crop Science, 5(4): 421-427.

Tavili, A., Saberi, M., Nasseri, H. and Etemad, V. 2008. Comparison effect of different methods of seed dormancy on seed germination of Simrnovia iranica. Scientific Journal of Rangeland, 4: 410-402.

Taylor, J.S. and Wearing, P.E. 1997. The effect of stratification on the endogenous levels of gibberellins and cytokinins in seeds of Douglas fir (Pseudotsuga menziesii (Mirb) Franco.) and sugar pine (Pinus ambertiana Doug). Plant Cell Environment, 2(2): 165-172. https://doi.org/10.1111/j.1365-3040.1979.tb00789.x

Vieira, A.R., Oliveira, J.A., Guimaraes, R.M., Vonpinho, E.V.R., Pereira, C.E. and Clemente, A.C. S. 2008. Marcador isoenzimático de dormência em sementes de arroz. Revista Brasileira de Sementes, Lavras, 30(1): 81-89. https://doi.org/10.1590/S0101-31222008000100011

Westwood, N.N. and Bjornstad, H.O. 2002. Chilling requirements of dormant seeds on 14 pear species as related to their climatic adaptation. Proceedings of the American Society of Horticultural Science, 92: 141-149.

Young, J.A. and Young, C.G. 1986. Seeds of Woody Plants in North America. Dioscorides Press, Portland, Oregan.

Zhang, Y., Lu, S.H. and Gao, H. 2012. Effects of stratification and hormone treatments on germination and physio-biochemical properties of Taxus chinensis. Genes and Development, 19: $1532-1543$. 
Research Article

\title{
Effect of Seed Dormancy Breaking Treatments on Germination and $\alpha-$ amylase Enzyme Activity in Seeds of Three Ecotypes of Astragalus (Astragalus cyclophyllu)
}

\author{
Akram Rostamipoor $^{1}$, Ali Moradi ${ }^{2, ~}$, Hamid Reza Eisvand ${ }^{3}$ \\ Extended Abstract
}

Introduction: Seed dormancy, as a technique to avoid environmental stress, is important in preserving plant species and could be of various types including physiological, physical, morphological and morphphysiological dormancy. Seed testa hardness is one of the main causes of dormancy in leguminous family plants. A common method for breaking seed dormancy in leguminous plants is the use of scarification treatments. Given that oxygen deficiency is a factor that induces dormancy, scarification treatments through acceleration of gas exchanges, especially oxygen and carbon dioxide, can reduce seed dormancy and finally increase germination percentages. In addition, priming with gibberellic acid can help dormancy breaking in plant species that have physiological dormancy, finally leading to germination. Therefore, the present study investigated seed dormancy and germination to find the most appropriate treatment for the elimination of seed dormancy in three ecotypes of Astragalus cyclophyllus.

Materials and Methods: A factorial experiment based on a completely randomized design with three replications was carried out at Agriculture Laboratory of Lorestan University in 2013. The first factor was three ecotypes of Astragalus Semirom, Damavand and Zanjan, and the second factor was seed dormancy breaking treatments. The applied treatments were: control, (mechanical scarification plus chilling time with 10,20 and 30 days prechilling at $4{ }^{\circ} \mathrm{C}$, mechanical scarification + gibberellic acid at concentrations of 400 and $500 \mathrm{ppm}$ for 48 hours, scarification with sulfuric acid $96 \%$ for 2 and 4 min, mechanical scarification and $2 \%$ potassium nitrate for $72 \mathrm{~h}$, mechanical scarification and gibberellic acid $400 \mathrm{ppm}$ for $48 \mathrm{~h}$ and 20 days prechilling. The measured indices included germination percentage, mean germination time, seedling length, seedling fresh weight, seedling dry weight and alpha-amylase activity.

Results: The results showed that the interactions between seed dormancy breaking treatments and ecotype were significant for all the traits. Based on the results of mean comparison, Damavand ecotype exhibited better performance in terms of most of the traits studied, as compared with Semirom and Zanjan ecotypes. Compared with the treatments applied, mechanical scarification plus gibberellic acid $400 \mathrm{ppm}$ was more effective in germination parameters and seedling vigor index. Mechanical scarification and gibberellic acid $400 \mathrm{ppm}$ for $48 \mathrm{~h}$ along with 20 days prechilling increased total germination percentage by an average of $67.68 \%$ in Semirom ecotype and was more effective in increasing the activity of $\alpha$-amylase enzyme.

Conclusion: It seems that seed dormancy of Astragalus cyclophyllus is not of physiological type and increased germination can be due to mechanical scarification in physical dormancy breaking and priming effect of prechilling and gibberellic acid.

\section{Keywords: a-amylase, Seed dormancy breaking treatments, Astragalus cyclophyllus}

\section{Highlights:}

1- The effect of different dormancy breaking treatments on seed germination was investigated.

2- Alpha-amylase activity of Astragalus Seed increased under dormancy breaking treatments.

\footnotetext{
Graduated M.Sc. Student, Department of Agronomy, Yasouj University, Yasouj, Iran

2 Associate Professor, Department, of Agronomy, Yasouj University, Yasouj, Iran

3 Associate Professor, Department of Agronomy, Lorestan University, Lorestan, Iran

*Corresponding author E-mail: amoradi@yu.ac.ir

http://dorl.net/dor/20.1001.1.23831251.1398.6.2.7.9

http://dx.doi.org/10.29252/yujs.6.2.15

CrossMark
} 